\title{
Analysis of the geographical diversification of financial instruments
}

\author{
Sztavrosz Bacsosz \\ University of Szeged, \\ Hungary \\ E-mail: \\ bacsosz.sztavrosz@gmail.com
}

The purpose of this research is to examine the effect of the geographical diversification of financial instruments on capital markets. Using geographical diversification in order to create a more effective portfolio would enable investors to use such diversification as a risk mitigation tool. Free capital market data, available to everyone, were primarily used in the research. This study aims to examine geographical diversification and its effectiveness in different regions as well as their historical changes. Historical analysis is not possible in

Keywords: countries lacking developed capital market. geographical diversification, A geographically diversified portfolio will rerisk, sult in efficiency gains over the long term. financial geography, Furthermore, the use of regional and global international portfolio, geographical exposure, globalisation capital market indexes can be an effective tool for geographic and geopolitical analysis of the relationships between countries and regions.

\section{Introduction}

The analysis of the risk return of investments is not only of interest to economics researchers but also to anybody who wants to invest and save. The relationship between risk-yield and time to achieve optimum investment performance is a critical factor. Banks, insurance companies and brokerage firms are constantly striving to create the ideal portfolio. Investors are constantly working on models and theories to achieve better performance and better returns. Is the weight of each market news measured efficiently, what price model should be used, and are investors suitably aware of the financial markets they are investing in? They invest significant energy and money to find the best answers to these questions. Complex quantitative models such as machine learning, deep learning, neural networks, big data (Ságvári 2019) and so on are used if necessary (Chatzis et al. 2018). Researchers also make significant efforts to identify the most efficient portfolio (Carrieri et al. 2003).

The use of geographic space and geographical diversification can provide many benefits to investors, and although the benefits of geographical diversification have been recognised, there are relatively few related studies. Some major global financial service providers (e.g. MSCI, Dow Jones, S\&P, and Bloomberg) have recognised the importance of geographical diversification and are fighting with their competi-

Regional Statistics, Vol. 9. No. 1. 2019: 13-31; DOI: 10.15196/RS090110 
tors in an attempt to create better models, region indexes to achieve better results. Despite the importance of the topic in most cases the relevance of geographical diversification has been ignored by investors, geographers, and economists.

This research presents the following questions: When creating a portfolio, what level of efficiency could improve the use of geographical diversification in making investment decisions? Who uses risk reduction method of geographical diversification in markets? The study also provides guidance on how financial and capital market indicators can be used by geography researchers. It is important to note that the results of this research can only be applied to countries and regions where there is an at-least-moderately-developed capital market. Where there is no real market, or only a very basic one, capital market indexes may reflect a completely unrealistic picture of a country's economic performance; thus, conclusions drawn on this basis would not be accurate.

\section{The role of geographical diversification in decision-making}

The first results of economic and geographic models in which economic events were not represented in a 'single-point economy' (e.g. Thünen, Christaller, Lösch's models) were revolutionary, but these models focused only on the primary and secondary sectors of the economy (Kovács 2014). This is mainly explained by the fact that these theories appeared in the $19^{\text {th }}$ and the first half of the $20^{\text {th }}$ century, when the third sector, including financial services, was undeveloped. Lösch's model contained some innovative elements, such as differences in interest rates or consumer price indexes at different geographic locations (Lösch 1954).

However, despite the successful work of Lösch, classical economic geography focused only on the real estate sector as it is easier to interpret it against the financial sector and it is more closely connected with geographic location. Hence, geography researchers were not interested in words like arbitrage, hedge, and financial diversification.

It should be noted that all aforementioned basic concepts can be organically linked to spatial attributes. Arbitrage can be defined with the following example: when a larger price difference occurs in geographically different markets, some investors (arbitrageur) obtain risk-free profits by buying in one market and selling in another. This process continues until both markets reach equilibrium, wherein prices in the two markets will be almost the same. To further justify the spatial nature of financial markets, consider how current financial markets and their intermediary systems have enabled individuals to invest their savings in markets other than those where the savings originated from.

Regional Statistics, Vol. 9. No. 1. 2019: 13-31; DOI: 10.15196/RS090110 
'Consider, for example, a resident of New York City who plans to sell her house and retire to Miami, Florida, in 15 years. Such a plan seems feasible if real estate prices in the two cities do not diverge before her retirement. How can one hedge Miami real estate prices now, short of purchasing a home there immediately, rather than at retirement? One way to hedge the risk is to purchase securities that will increase in value if Florida real estate becomes more expensive. This creates a hedging demand for an asset with a particular risk characteristic. Such demands lead profit-seeking financial corporations to supply the desired goods: observe Florida real estate investment trusts (REITs) that allow individuals to invest in securities whose performance is tied to Florida real estate prices. If Florida real estate becomes more expensive, the REIT will increase in value. The individual's loss as a potential purchaser of Florida real estate is offset by her gain as an investor in that real estate. This is only one example of how a myriad of risk-specific assets are demanded and created by agents in the financial environment.'

(Bodie et al. 2001., p. 19.)

The citation above has been commonly used in the financial study courses at renowned Hungarian and foreign universities. This simple example can illustrate how risk coverage methods that consider the geographic space may have a bearing on the financial world. The merit of the authors is that the geographical risk sharing techniques are presented in a book under a short chapter called 'international diversification'. However, this does not apply to many other finance instructor's manuals. A number of studies (Solnik 1974) have highlighted that the use of geographical diversification can improve portfolio selection, as many elements of the wider portfolio of financial assets are more beneficial for smaller investors. This fact does not require a long explanation, as it is obvious that a small country, or a small financial market, will be considered small by investors. Investors may not be able to choose from a sufficient variety and quality of securities for obtaining the optimum portfolio, which drives them elsewhere.

The geographical diversification of an investment portfolio, that is, the spread of risk between geographic areas, may have many advantages. However, it can be argued that both foreign and domestic securities have been used by institutions and individual investors to analyse traditional risk sharing methods. ${ }^{1}$ The high-level mathematical risk assessment techniques applied in modern advanced capital markets were only developed at the end of the 20th century. ${ }^{2}$ This may be explained by the disproportionately minor role of the exploitation of the opportunities offered by the geographic space in the application and research of modern portfolio theories. The following is one proof: in some finance books by famous authors, there are

${ }^{1}$ We primarily mean risk sharing according to company size and industry.

2 Milton Friedman, the then well-known economist, criticized Harry Markowitz's Study of Portfolio Theory (1952), arguing that what Markowitz wrote about has nothing to do with economics. However, in 1990, he received the Nobel Prize for Economics for developing the theory of portfolio selection. (Bernstein 2005)

Regional Statistics, Vol. 9. No. 1. 2019: 13-31; DOI: 10.15196/RS090110 
only a few pages on a brief outline of the possibilities. Of course, there are some exceptions in the domestic and foreign literature (Pálosi-Németh 2007).

We briefly examined the monthly reports on domestic and foreign funds and found that, in addition to the list of countries that attempt to highlight the geographic exposure of individual securities, they do not play a significant role in geographical diversification. A similar conclusion can be drawn if we examine the fundamental or technical analysis of brokerage firms. In many cases, risk indicators that require a higher level of mathematical background such as VaR, Beta, Alpha, Sharpe, and so on are presented. However, the spread of risk in geographic space is not clearly or comprehensively presented. For example, the breakdown of investments by country is often oversimplified. What could explain the fact that geographical diversification, used as a risk mitigation technique, is not treated as a more important factor?

The main reason for the ignorance regarding geographical diversification may be that its significance is not easily perceived. The increasingly rapid and unrestricted flow of capital in the global economy, online 24-hour trading platforms, and the spread of a wide range of electronic currencies can give the impression that the geographic risk of financial and capital market products is largely meaningless.

\section{The importance and theoretical framework of geographical di- versification}

Although financial geography has been discussed for more than two decades, only a few related studies are to be found in the Hungarian literature. Economists have also marginalised the study of spatiality in their financial research. O'Brien (1992) predicts the 'death of geography' as a result of globalisation. According to his hypothesis, the significance of the geographical space is lost due to the ongoing deregulation at the time. Instead of physical distance, the cost of obtaining information will be the most important factor in business decision-making as distance is easily overcome by electronic money transfers and dematerialised securities (O'Brien 1992). He believes that the importance of geographic location as a factor for economic development is decreasing. To understand the benefits of diversification, it is essential to have a basic knowledge of portfolio theory as similar tasks and problems are encountered in the analysis, selection, and allocation of securities while using and examining geographical diversification.

Markowitz's Portfolio Selection (1952), published in the Journal of Finance, explains that increasing diversification reduces the variance of the portfolio's yield. ${ }^{3}$ Since then, it has also been proven that by increasing the number of risky assets

\footnotetext{
${ }^{3}$ Variance does not mean anything other than a squared standard deviation. The probability calculation is a common indicator used to characterize the distributions.
}

Regional Statistics, Vol. 9. No. 1. 2019: 13-31; DOI: 10.15196/RS090110 
(i.e. shares in the portfolio), volatility (i.e. exchange rate volatility) can be significantly reduced, but the so-called market risk cannot be completely eliminated. The risk that cannot be eliminated despite diversification is called market risk or systematic risk. Market risk can be explained by threats across a country's economy, which can affect all companies. In such cases, prices may move regardless of how diversified a portfolio is. On the other hand, specific risk or otherwise diversifiable risk can be reduced through diversification (see Figure 1).

\section{Difference between specific risk and market risk by increasing number of securities}

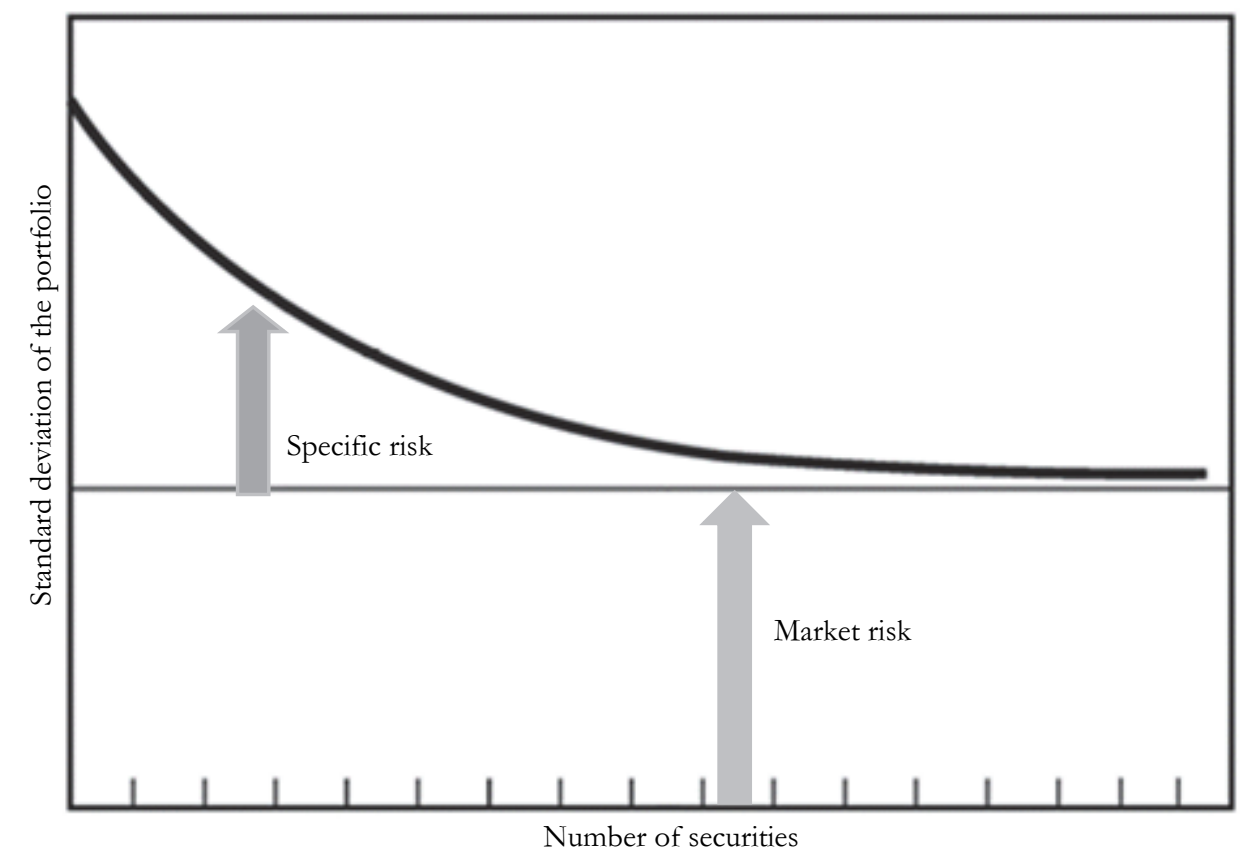

Source: Own elaboration based on Bodie et al. (2001).

Generally speaking, we can eliminate the specific risk of the portfolio by using 15-20 financial instruments. It is also clear from Figure 2 that by increasing the number of securities, the individual risk decreases to a little extent until no increase in efficiency can be achieved by increasing the number of elements (GriffinKarolyi 1998).

We define market risk as the financial and capital markets of a particular country. A country's national economy may not follow global trends and may slip into recession. For example, an investor places all their savings in a well-diversified portfolio,

Regional Statistics, Vol. 9. No. 1. 2019: 13-31; DOI: 10.15196/RS090110 
invests in the Russian stock exchange (e.g. by buying an index product ${ }^{4}$ ), and then realises that the Russia-Ukraine conflict is devaluing their assets. In this case, the market risk of that country was not eliminated by the investor. Figure 2 also reveals that further efficiency gains can be achieved through a cross-border geographically diversified portfolio.

\section{Domestic vs. international equity portfolio risk}

Figure 2

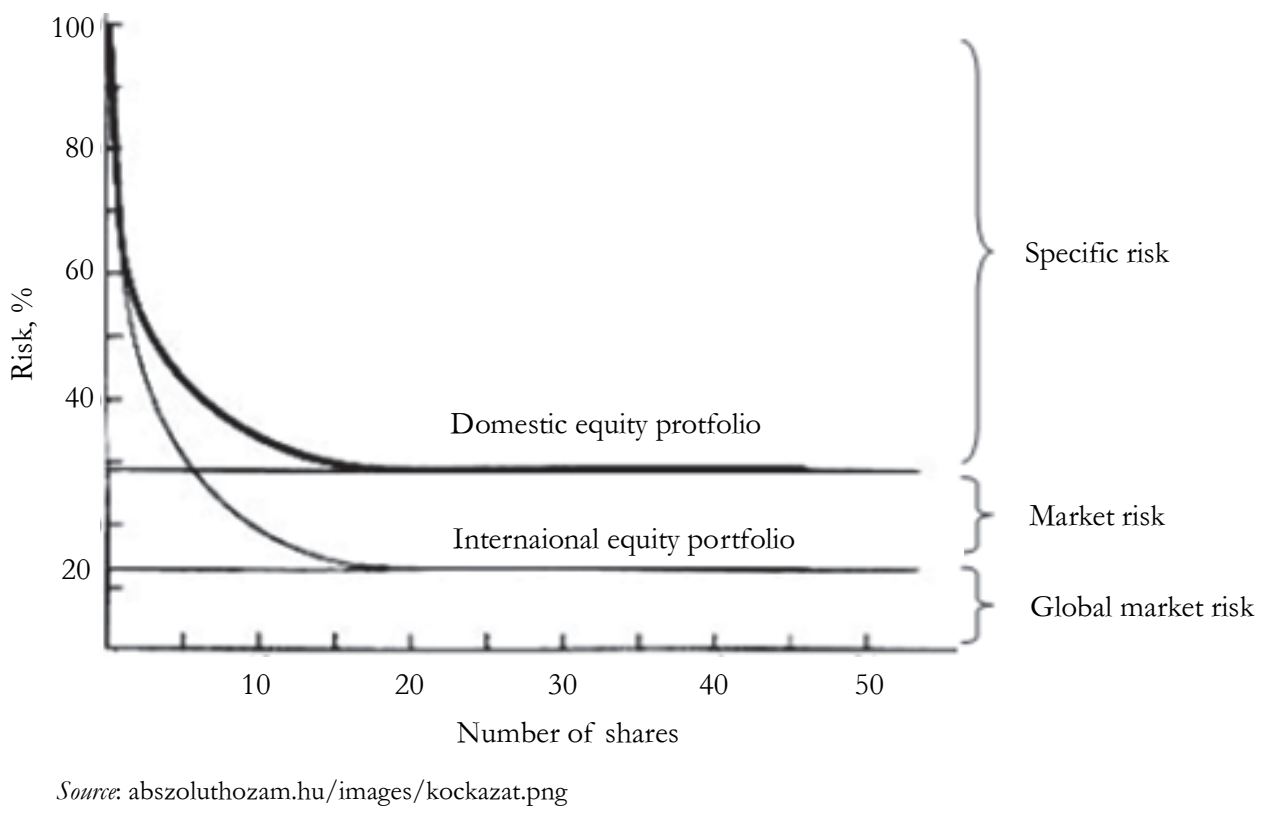

In terms of risk, this study focuses on diversification, particularly the sharing of risk between industries. The financial literature rarely refers to other risk diversification opportunities. However, as a truly effective portfolio can be created, above all, by investing in different industries, where we consider the size of the companies as they are at different stages of their lifecycles, our portfolio includes securities with sufficiently differentiated growth potential and stability.

Figure 3 reveals that the use of structural diversification alone cannot be sufficient for investors to create the most effective portfolio in terms of their risk profiles. However, when explaining diversification, the finance literature mainly focuses on structural diversification. Markowitz and Sharpe, the pioneers of risk sharing, explain risk-yield relationships with the correlation between A and B companies in the investment universe. At the same time, if we look more closely at Figure 3, it is

${ }^{4}$ A type of security that tries to copy the performance of some capital market indicator.

Regional Statistics, Vol. 9. No. 1. 2019: 13-31; DOI: 10.15196/RS090110 
striking that cross-sectional diversification is merely one means of spreading risk. There are other options that can be used to spread risk, and efficiency can be increased by careful selection of company size and the use of geographical diversification (Beckers et al. 1996). Moreover, buying and selling financial instruments at different times also has the potential of reducing the risk of the portfolio.

\section{Possible ways of spreading risk}

Figure 3

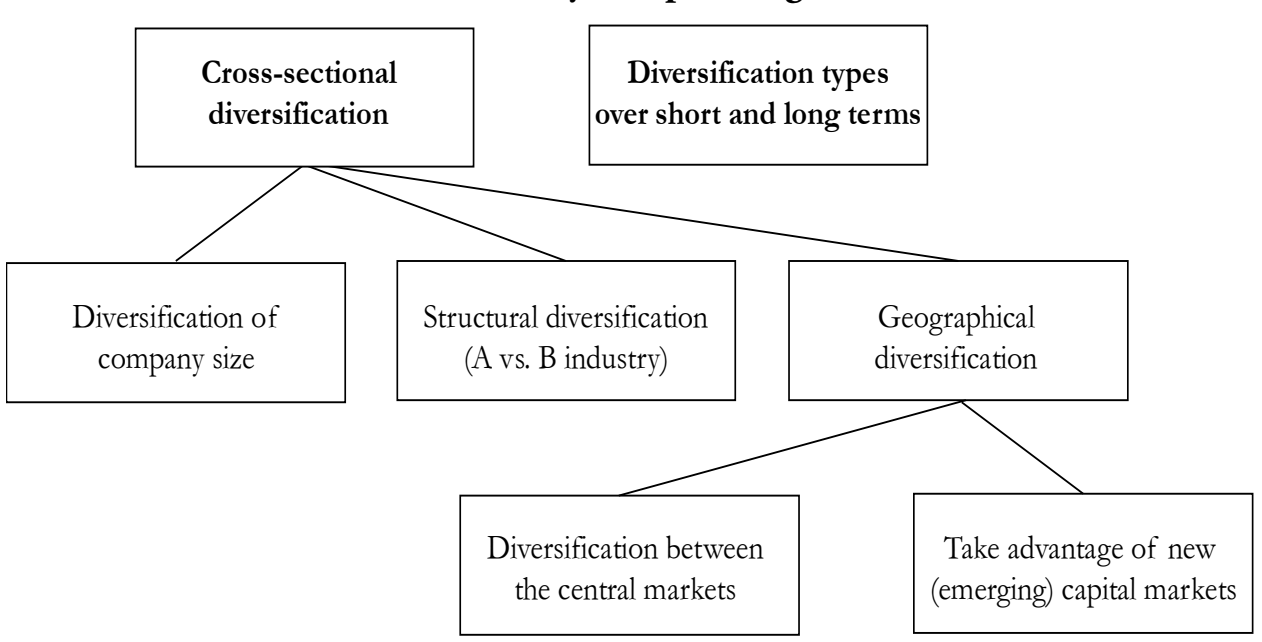

Source: Pálosi-Németh (2007).

Institutions in financial markets, such as banks, insurance companies, brokerages, and funds, offer many financial products and services that attempt to reduce the risks in the aforementioned manner.

\section{Efficiency of geographical diversification}

Institutions (banks, insurance companies, pension funds, other funds, etc.) offer not only investment products which one can open speculative positions with, but also financial instruments that can be used to significantly reduce risk; however, as a result, the composition of the savings changes.

One seldom discussed feature of financial intermediation is that it not only collects geographically scattered savings, but also transfers savings through different risk investment products to different points of the geographical space, thereby significantly reducing the cost of resources and risk for each investment.

Solnik (1974) have already demonstrated how the use of geographical diversification can result in significant efficiency gains. As shown in Figure 4, which illustrates the standard deviation of equally weighted portfolios of different sizes, the authors demonstrate the weaknesses of an exclusively US investment-focused portfolio. The

Regional Statistics, Vol. 9. No. 1. 2019: 13-31; DOI: 10.15196/RS090110 
value of $20 \%$ on the vertical axis means that the deviation of the diversified portfolio is $20 \%$ of the standard deviation of a single share portfolio. It is clear that significant risk reduction can be achieved if, for example, in addition to US shares, we also hold foreign shares in our portfolio. Figure 4 also illustrates that a geographically well-diversified portfolio reduces the risk of the domestic portfolio by almost a half.

\section{Advantages offered by international diversification}

Figure 4

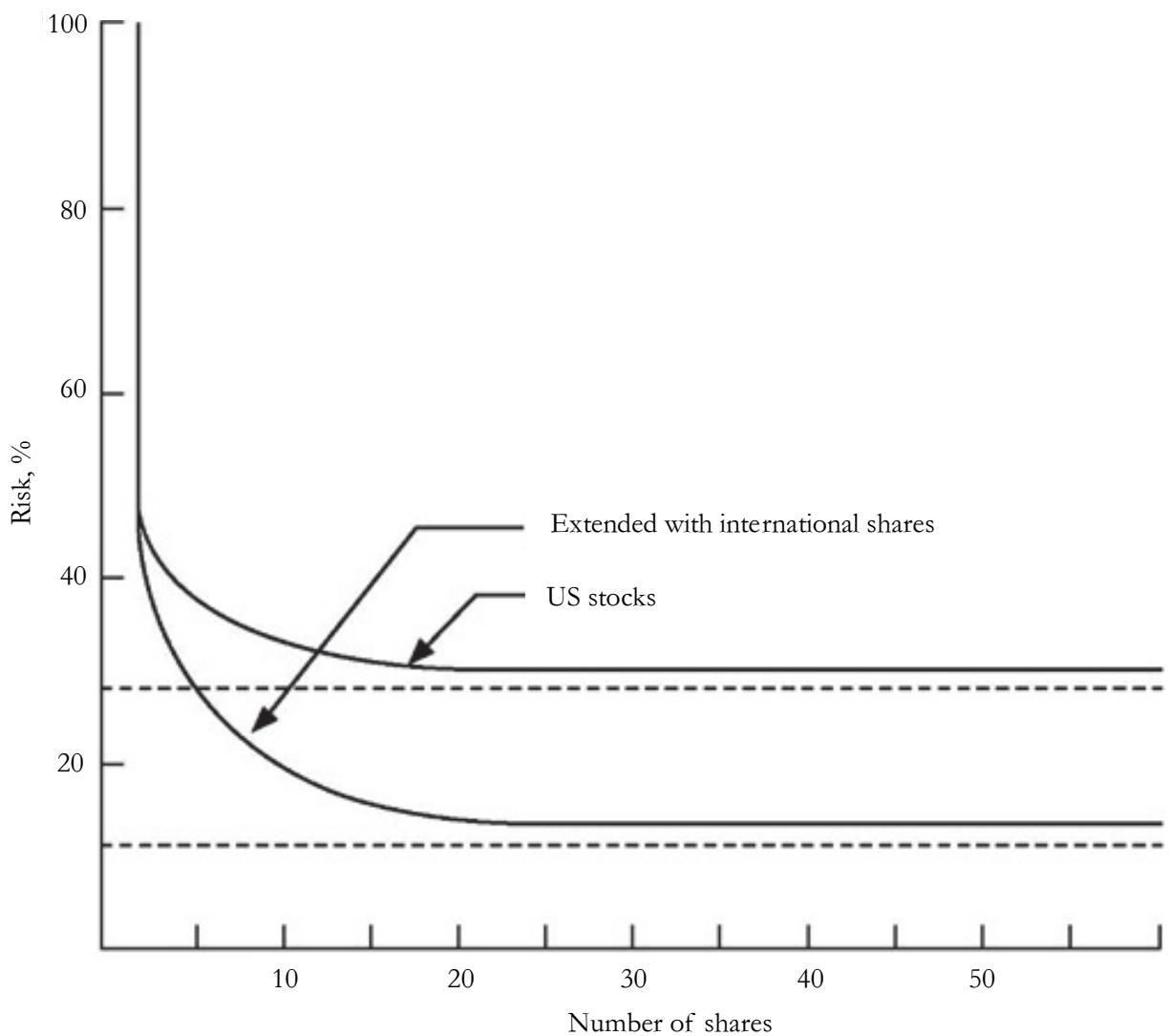

Source: Solnik (1974).

According to the following table, the market capitalisation ${ }^{5}$ of the US accounts for over one third of the total capitalisation. This means that investors who only favour the capital market of their own country cannot exploit the benefits of diversification.

\footnotetext{
${ }^{5}$ Multiplied by the price and number of shares. This is nothing more than the market value of the company.
} 
The 25 largest capital markets, 2017

\begin{tabular}{|c|c|c|}
\hline Country & $\begin{array}{l}\text { Market capitalisation, } \\
\text { USD million }\end{array}$ & $\begin{array}{l}\text { Percentage of total } \\
\text { capitalisation, } \%\end{array}$ \\
\hline United States & $32,120,703$ & 40.54 \\
\hline China & $8,711,267$ & 11.00 \\
\hline Japan & $6,222,825$ & 7.85 \\
\hline United Kingdom & $3,605,561$ & 4.55 \\
\hline France & $2,749,315$ & 3.47 \\
\hline Canada & $2,367,060$ & 2.99 \\
\hline India & $2,331,567$ & 2.94 \\
\hline Germany & $2,262,223$ & 2.86 \\
\hline South Korea & $1,771,768$ & 2.24 \\
\hline Switzerland & $1,686,497$ & 2.13 \\
\hline Australia & $1,508,463$ & 1.90 \\
\hline South Africa & $1,230,977$ & 1.55 \\
\hline Sweden (OMX Nordic) & $1,122,815$ & 1.42 \\
\hline Netherlands & $1,100,105$ & 1.39 \\
\hline Brazil & 954,715 & 1.21 \\
\hline Spain & 888,838 & 1.12 \\
\hline Singapore & 787,255 & 0.99 \\
\hline Russian Federation & 623,425 & 0.79 \\
\hline Italy & 561,428 & 0.71 \\
\hline Thailand & 548,795 & 0.69 \\
\hline Indonesia & 520,687 & 0.66 \\
\hline Malaysia & 455,772 & 0.58 \\
\hline Saudi Arabia & 451,379 & 0.57 \\
\hline Belgium & 437,794 & 0.55 \\
\hline Mexico & 417,021 & 0.53 \\
\hline Total & $79,224,525$ & 100.00 \\
\hline
\end{tabular}

Note: Deviation from 100.00 results from rounding.

Source: Own calculation based on databank.worldbank.org and sdw.ecb.europa.eu

However, we can also see that the global capital market is heavily concentrated and the market capitalization of the top 25 countries is 95.22 , suggesting that some markets may be so small that large hedge and pension funds may influence market prices through their investments. Only five countries have market capitalisation

Regional Statistics, Vol. 9. No. 1. 2019: 13-31; DOI: 10.15196/RS090110 
exceeding 3 of the total global capitalisation: the US, China, Japan, the United Kingdom, and France. ${ }^{6}$

In the context of the theoretical framework, it has been shown that if we add additional assets to the portfolio, where the correlation between them is not strong our portfolio may become more effective. Thus, the yield per unit may increase or be obtained at a lower risk. In global financial markets, capital flows smoothly between countries; as a result, we can create more diversified portfolios and make these benefits cheaper and faster. However, investors face new issues by spreading risks geographically. Examples include country legislations, political risks, and capital market traditions, as well as currency risks.

However, in their decision-making, investors mainly select the portfolio mix based on their risk preference. In investment decision-making, the size of the portfolio, investor's risk tolerance, time horizon of the investment, and returns on alternative investments can play a decisive role for many factors. It is difficult to determine which of these are the most important.

At the same time, small domestic investors and large international institutional investors have completely different attitudes. They often react differently, and their opinions may be different if they have to place their financial assets in developed or emerging markets. Individual investors often overstate information about their own country, so domestic markets play a greater role in their portfolio. This phenomenon is referred to as 'Home Bias' (Caprio 2012). This phenomenon exists in almost every market, but by examining its scale, we can obtain different results regarding geographic space and distant time horizons.

Figure 5

The major classes of investments

\begin{tabular}{c|c|c|c}
\hline Asset type & $\begin{array}{c}\text { Geographical } \\
\text { exposure }\end{array}$ & Industry & Investment strategy \\
\hline $\begin{array}{c}\text { Equity, bond, } \\
\text { property }\end{array}$ & $\begin{array}{c}\text { Developed vs. } \\
\text { emerging; } \\
\text { Domestic vs. } \\
\text { international }\end{array}$ & $\begin{array}{c}\text { Technology, } \\
\text { pharmaceuticals, } \\
\text { energy }\end{array}$ & $\begin{array}{c}\text { Growth vs. risk } \\
\text { aversion }\end{array}$ \\
\hline
\end{tabular}

Overweighting domestic markets can be explained by the fact that, despite rapid communication tools, information asymmetry ${ }^{7}$ in financial markets increases with the increase of geographical distance. ${ }^{8}$ However, 'At the beginning of the 1980s, investors, even institutional investors or individual investors invested only 5 of their money in foreign securi-

\footnotetext{
${ }^{6}$ It is important to note that a particular security may not only be traded in one country, so in many cases it is very difficult to determine its geographical location.

7 The unequal distribution of information among investors in the financial market, which is often due to the fact that one investor has an advantage over the other investor.

${ }^{8}$ The overweighting of the domestic market is not only due to lack of information. As domestic market is free from exchange rate risk, in the most cases the transaction costs are lower.
}

Regional Statistics, Vol. 9. No. 1. 2019: 13-31; DOI: 10.15196/RS090110 
ties. On the other hand, the 15-20 ratio has become quite usual, but in some smaller countries with a developed financial market even one third of the portfolio exceeds the ratio of foreign assets'. (Gál 2010., p. 16.)

This quote demonstrates that cross-border risk sharing techniques are becoming increasingly important. Modern investors purchase fewer direct financial instruments, they are buying instead indirect financial instruments (e.g. investment funds, index funds, ETFs [exchange traded funds], certificates, etc.), largely due to the securitisation ${ }^{9}$ revolution over the last few decades.

Figure 6 illustrates that the efficiency of geographical diversification has declined significantly, primarily because of the fact that, as a result of globalisation, a significant proportion of investors favour a larger share in developed markets in their portfolio.

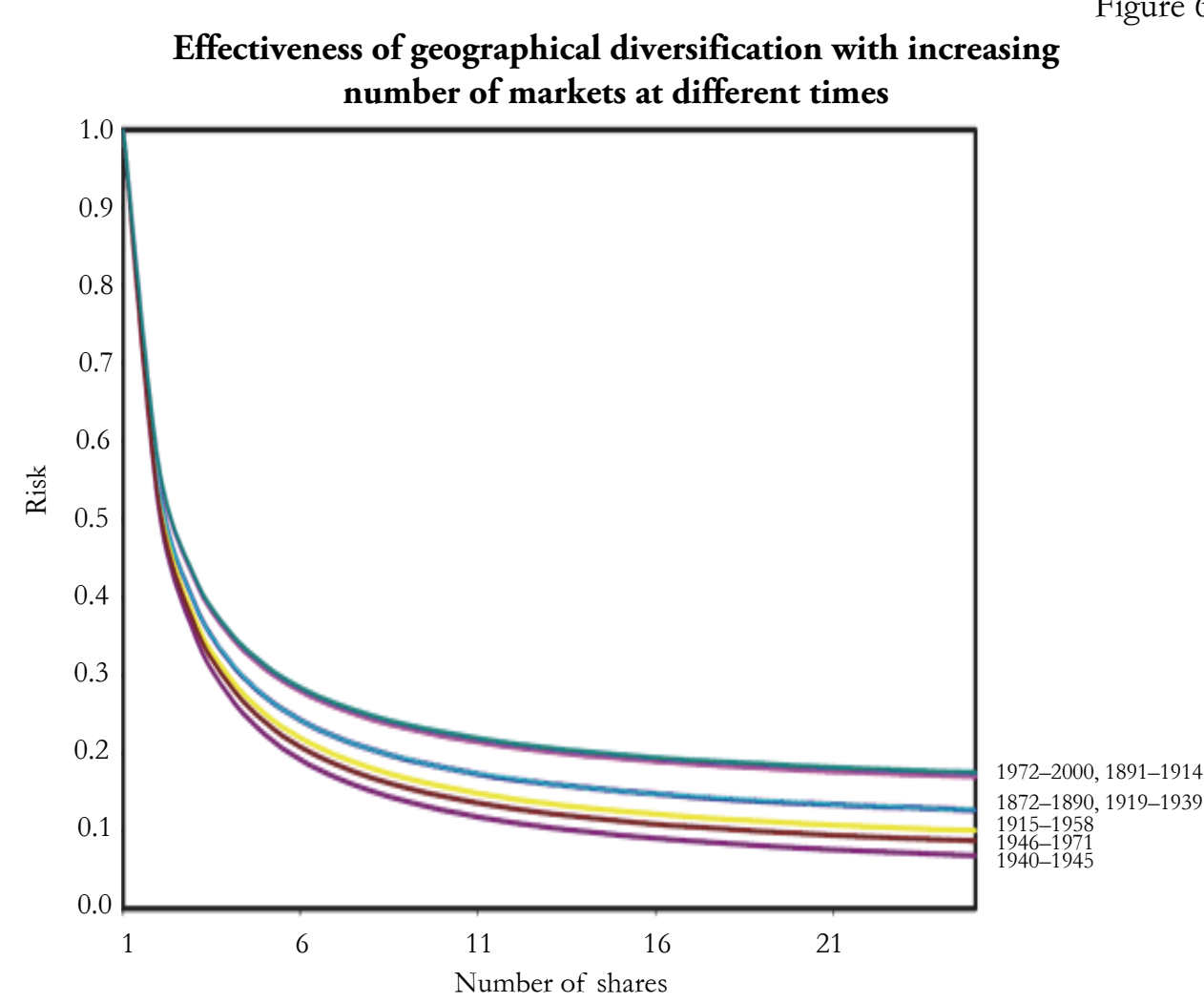

Source: Goetzmann et al. (2001).

However, dozens of new financial products are available and these financial instruments are becoming increasingly complex or difficult to operate across larger geographical distances. Thus, at the outbreak of the 2008 financial crisis, large geo-

${ }^{9}$ When bypassing lending banks, companies directly receive money as a result of securitization.

Regional Statistics, Vol. 9. No. 1. 2019: 13-31; DOI: 10.15196/RS090110 
graphical distances completely blurred key information for investors and severely impacted the world's money and capital markets (see Figure 7) (Zsibók 2017, Kocziszky et al. 2018).

\section{Historical review of the correlation of capital markets}

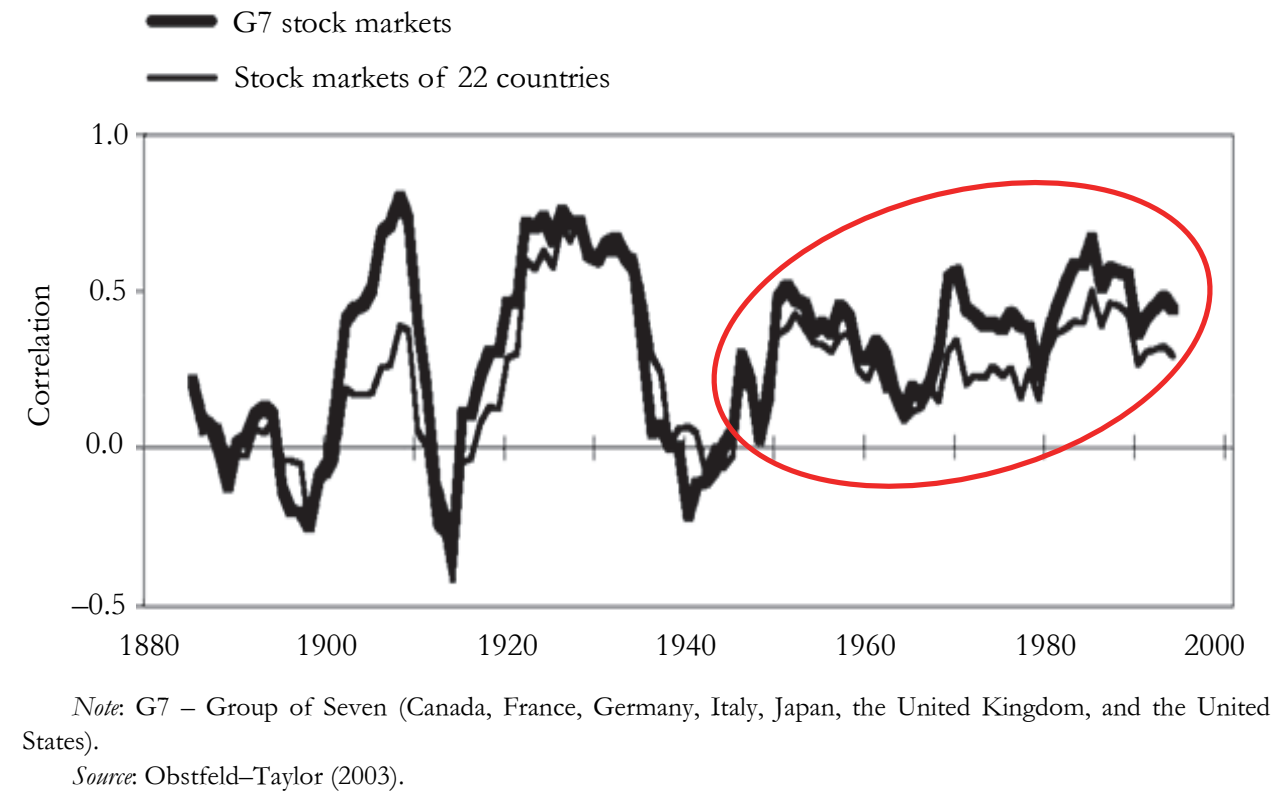

\section{Geographical diversification of the markets}

The most important research question in this study is how much more could be achieved if portfolios were developed with greater consideration of geographical risk spreading. Figure 8 illustrates changes in the variability of two diversified portfolios if a geographically diversified portfolio is favoured. 
Figure 8

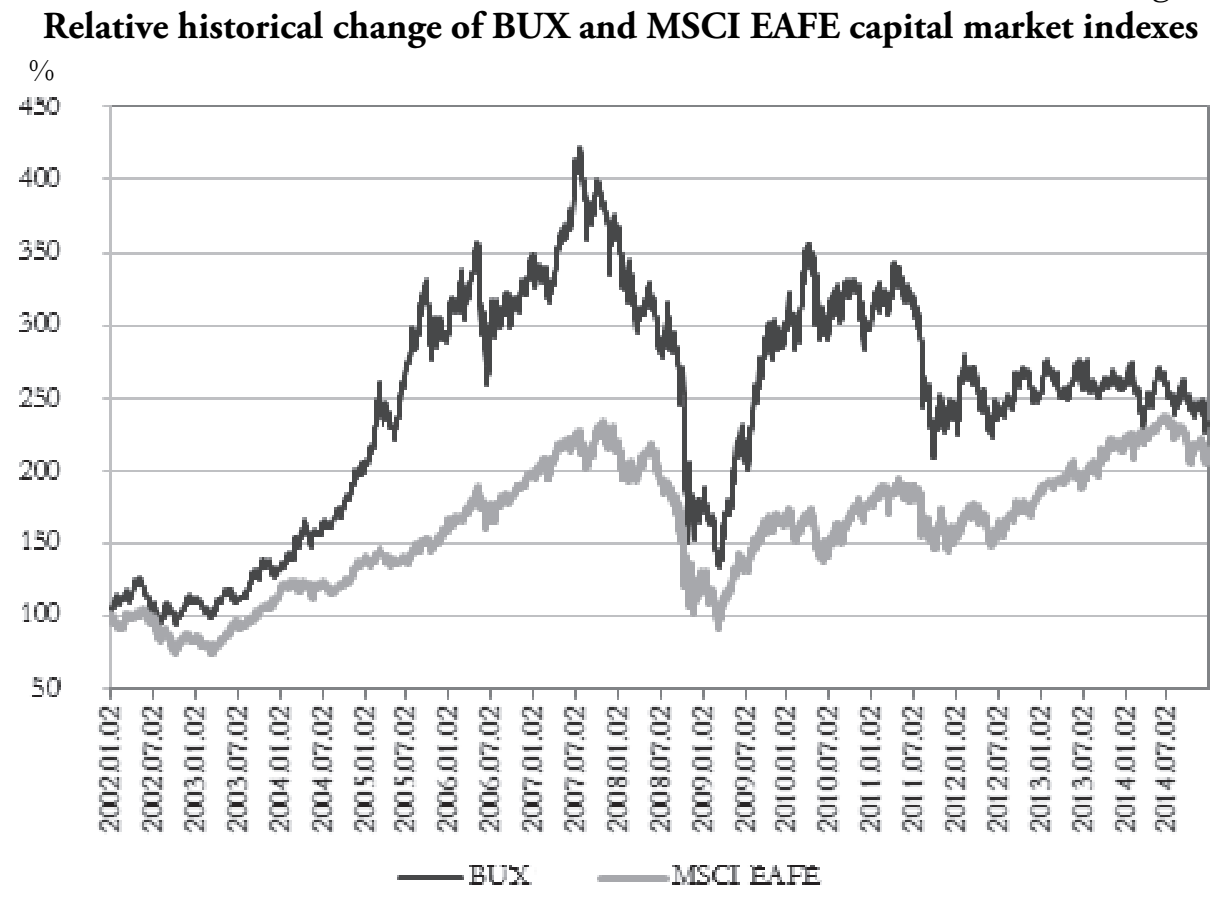

Note: Here and in Figure 9, BUX - Budapest Stock Exchange index. MSCI refers to MSCI Inc., EAFE stands for Europe, Australasia and Far East.

Source: Own elaboration based on Yahoo Finance (https:// finance.yahoo.com).

The following formula is suitable for the correct comparison of dispersion indicators in different markets. Relative dispersion is measured with the coefficient of variation $(\mathrm{CV})$, which is computed as:

$$
C V=\frac{s_{x}}{\bar{X}}=\frac{\text { standard deviation of } x}{\text { average value of } x} .
$$

A direct comparison between the dispersion of the two or more distributions is sometimes not meaningful due to the relatively large difference in their means. The following is a concrete example of what the CV shows. ${ }^{10}$ The numerator is the standard deviation of annualised yields, while the denominator is the average of annualised returns. We obtain the following results:

$$
\begin{aligned}
& C V_{\text {BUX }}=0.3098 / 0.1065=2.9103 \\
& C V_{\text {MSCI EAFE }}=0.2010 / 0.0753=2.6694 .
\end{aligned}
$$

${ }^{10}$ The period was from $01 / 02 / 2002$ to $12 / 31 / 2014$.

Regional Statistics, Vol. 9. No. 1. 2019: 13-31; DOI: 10.15196/RS090110 
A higher CV value is worse because it indicates a higher risk for the same return. That is, the investor obtains a smaller return for the same risk. The efficiency of geographical diversification is well demonstrated by the CV. The geographically well-diversified MSCI EAFE portfolio performs better than the single-market BUX portfolio, meaning there is less risk for one unit of return.

$$
\begin{aligned}
& C V \text { S\&P } 500=0.1668 / 0.0566=2.9445 \\
& C V_{\text {MSCI EAFE }}=0.2010 / 0.0753=2.6694 .
\end{aligned}
$$

It is clear that a high number of securities alone is not enough to maximise the efficiency of our portfolio if it is not geographically diversified. The S\&P 500 index consists of 500 shares but performs worse than the Budapest Stock Exchange index $(\mathrm{BUX})^{11}$ in the examined term. Despite the fact that the S\&P 500 index has a high number of shares and a low standard deviation, it is still the worst investment if we consider the other two portfolios. It is also clear that standard deviation alone is not suitable for measuring the risk of an investment (thus, variance is not suitable either).

Figure 9 presents the three most important Eastern European capital market indexes (BUX, WIG ${ }^{12}, \mathrm{PX}^{13}$ ) in the past 20 years, relative to each other. The budgetary crisis in 2008 led to a significant fall in the capital market indexes of all three countries. ${ }^{14}$ However, it is also apparent that although these countries began with a similar level of development after the regime change, the stock indexes of each country perform differently. The yield performance of an investor who preferred the Hungarian stock market instead of the Czech stock exchange since 1998 is three times better. We can also conclude that up until 2011, these three stock indexes were very similar, that is, the correlation between them was significantly positive. The Polish and Hungarian stock markets have outperformed the Czech stock exchange since $2013 .{ }^{15}$

\footnotetext{
${ }^{11}$ BUX consists of approximately 12-24 companies' shares.

12 Warsaw Stock Exchange index.

${ }^{13}$ Prague Stock Exchange index

${ }^{14}$ It is important to note that in Hungary the per capita GDP has decreased more in the next few years than in the neighbouring countries (Egedy 2012).

${ }^{15}$ It is important to note that different results can be obtained by changing the study period. By selecting the longest time series this study attempted to draw conclusions from the three most important Eastern European stock indexes. In 2018, the relative performance of the Czech stock market index was similar that of the Polish stock market index.
}

Regional Statistics, Vol. 9. No. 1. 2019: 13-31; DOI: 10.15196/RS090110 
Relative historical change of BUX, WIG, and PX capital market indexes

Figure 9

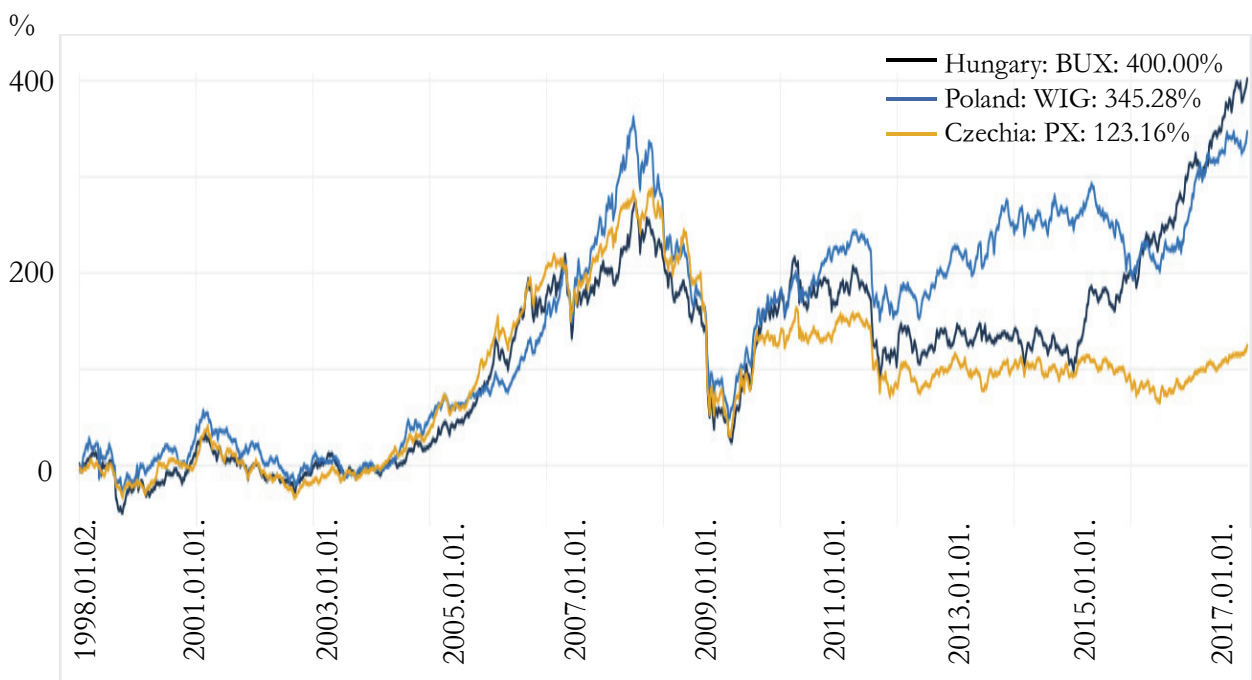

Note: WIG - Warsaw Stock Exchange index; PX - Prague Stock Exchange index.

Source: Own elaboration based on The Wall Street Journal data.

Figure 10 shows that over a thirteen-year period our return is roughly the same as the investors' who invested in the first days of January 2002, but instead of the MSCI EAFE index ${ }^{16}$, chose only BUX. We consider an example of what happens when the developing market index, BUX, is replaced by one of the most accepted and well-known developed US capital markets index: the S\&P500. The figure clearly shows that the S\&P 500 index was not as volatile as BUX and even more stable than the MSCI EAFE index. The same conclusion is reached if we consider the MSCI EAFE 1.0366 Beta indicator. The Beta value of 1.0366 means that in the case of the 1 yield of the S\&P 500 index, a 1.0366 shift in the same direction was observed. We know that if Beta $>1$, the selected portfolio is more risky than the selected reference index.

This also means that a yield of 1 of the positive return is higher if we keep the MSCI EAFE index in our portfolio instead of the S\&P500 index, since the Beta value of 1.0366 shows that the MSCI EAFE index is more risky. This is remunerated by the market with a premium yield.

${ }^{16} \mathrm{It}$ is one of the oldest global capital market indexes, which was started by Morgan Stanley in December 1969. The index includes securities from 23 developed countries, but the primary goal was not to include American and Canadian papers.

Regional Statistics, Vol. 9. No. 1. 2019: 13-31; DOI: 10.15196/RS090110 
Relative historical change of S\&P 500 and MSCI EAFE capital market indexes

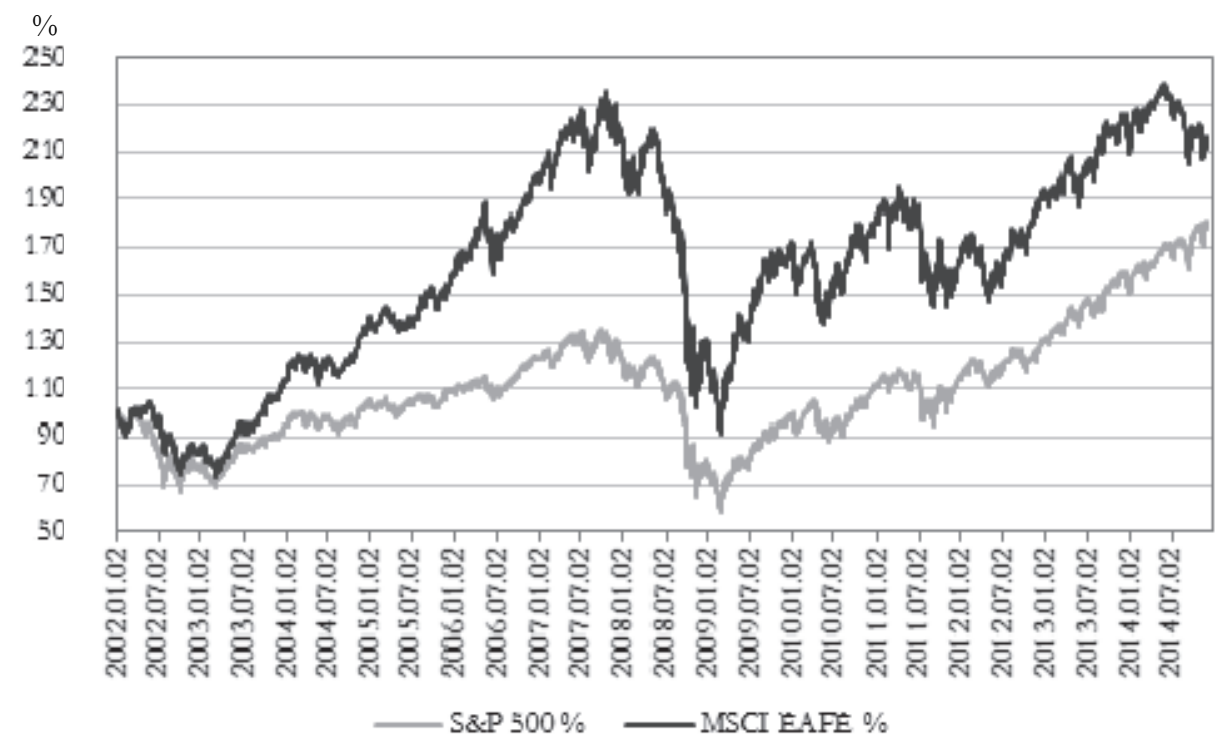

Note: S\&P500 - an American stock market index.

Source: Own elaboration based on Yahoo Finance (https:// finance.yahoo.com).

Beta is a risk indicator with a regression analysis that can yield different results depending on the benchmark ${ }^{17}$. In addition, different Beta results are obtained by selecting different time intervals. It is very important to clarify that the correlation coefficients can change significantly in the increasingly globalised economy during major market recessions and we can observe a stronger correlation relationship. This means that if there is a fall in prices in some large capital markets, prices are likely to fall in other markets. This spillover effect was observed during the 2008 financial crisis.

As previously mentioned, a negative Beta-denominated portfolio can easily move in the same direction as the Beta reference index during a crisis. For risk analysis with Beta, it is important to note what is chosen as the market reference index. Although the capital market index of the S\&P 500 can be a good indication of the mood of global capital markets, there are still many challenges. For example:

- The US capital market mood may have an unavoidable impact on any other capital market even though it only shows the performance of the US capital market.

17 'One of the most important, but often overlooked, influences on the asset allocation decision is the choice of the benchmark by which to measure risk. In mean variance optimization, the objective is to maximize return per unit of portfolio risk. The investor's benchmark defines the point of origin for measuring risk. That is, it represents the minimum-risk portfolio.' (Fischer-Litterman 1992, p. 38.)

Regional Statistics, Vol. 9. No. 1. 2019: 13-31; DOI: 10.15196/RS090110 
- We do not always obtain an accurate picture of risk-yield research when we compare the markets in developed and emerging economies.

- Although the S\&P 500 index is sufficient, it is not always suitable for global or regional capital market analysis.

Faced with these problems, many news service providers, analysts, and fund managers have attempted to create their own regional and global capital market indexes. ${ }^{18}$

\section{Conclusion}

This paper aimed to highlight the fact that the global financial market provides a good environment for diversification as it offers a great deal of variation opportunities to optimise risk-return. Most of the related methods have already been developed, and instead of relying on existing, mainly ex-post data, real-time data may help achieve more relevant and forward-looking conclusions, which are not outdated and are focused on the future.

The importance of the topic is also verified by the fact that geographical diversification can be used in everyday financial decision-making. Indeed, as demonstrated in this study, achieving the best performance is not only possible, but also useful. Several studies have already shown that investors who do not consider the international capital market will create lower performing securities portfolios (Solnik 1982).

The international and cross-border investments presented herein may illustrate the diversification benefits offered by the geographic space used in the selection of the portfolio, which is why there is a much wider choice of financial instruments. However, in terms of international investment, there are a number of problems that rarely occur in domestic markets. One of the most obvious problems is that, with the increase in geographical distance, the investor faces significant information asymmetry, which can generate dozens of added problems in addition to currency risks, political risks, regulatory decisions, and different taxation and accounting practices. However, these kinds of problems can be adequately addressed through the diversification methods already described.

It should be emphasised that a completely different answer to the research questions would have been obtained if the fact that the efficiency of geographical diversification changes over time were not considered. We also experience different levels of efficiency when small, medium, or large companies are included in our portfolio (De Moor-Sercu 2010). However, other authors have previously highlighted that there are substantial benefits to geographical diversification beyond the amounts attributable to industrial or currency diversification (Heston-Rouwenhorst 1994).

${ }^{18}$ For example, BBC Global 30 index, Dow Jones Global Total Stock Market index, FTSE Euro 100.

Regional Statistics, Vol. 9. No. 1. 2019: 13-31; DOI: 10.15196/RS090110 


\section{REFERENCES}

BeCkers, S.-CONNOR, G.-CuRds, R. (1996): National versus global influences on equity returns Financial Analysts Journal 52(2): 31-39. https://doi.org/10.2469/ faj.v52.n2.1978

BernsteIn, L. P. (2005): Capital Ideas - The Improbable Origins of Modern Wall Street Corvina Press, Budapest.

Bodie, Z.-KAnE, A.-MArcus, J. A. (2001): Essentials of Investments, $5^{\text {th }}$ Edition McGraw-Hill Press, New York.

Brooks, R.-Del Negro, M. (2005): Country versus region effects in international stock returns source Journal of Portfolio Management 31(4): 67-72. https://doi.org/10.3905/jpm.2005.570152

CAPrIO, G. (2012): The Evidence and Impact of Financial Globalization University Press, Cambridge.

CArrieri, F.-ErrunZA, V.-SARkissian, S. (2003): The Dynamics of Geographic versus Sectoral Diversification: A Causal Explanation McGill University Press, Montreal.

Chatzis, S. P.-Siakoulis, V.-Petropoulos, A.-STAVroulakis, E.-VlachogianNakis, N. (2018): Forecasting stock market crisis events using deep and statistical machine learning techniques Expert Systems with Applications 112: 353-371. https://doi.org/10.1016/j.eswa.2018.06.032

DE MOOR, L.-SERCU, P. (2010): Country vs. sector effects in equity returns and the roles of geographical and firm-size coverage Small Business Economics 35(4): 433-448. https://doi.org/10.1007/s11187-008-9170-6

EGEDy, T. (2012): A gazdasági válság hatásai városon innen és túl Területi Statisztika 52(4): 335-352.

Fischer, B.-LitTerman, R. (1992): Global Portfolio Optimization Financial Analysts Journal 48(5): 28-43.

GÁL, Z. (2010): Pénzügyi piacok a globális térben: a válság szabdalta pénzügyi tér Akadémiai Kiadó, Budapest.

Goetzmann, N. W.-LingFeng, L.-Rouwenhorst, G. K. (2001): Long-term global market correlations Journal of Business 78(1): 1-38. https://doi.org/10.1086/426518

Griffin, J. M.-Karolyi, G. A. (1998): Another look at the role of the industrial structure of markets for international diversification strategies Journal of Financial Economics 50(3): 351-373. https://doi.org/10.1016/S0304-405X(98)00041-5

Heston, S.-Rouwenhorst, G. (1994): Does industrial structure explain the benefits of international diversification? Journal of Financial Economics 36(1): 3-27. https://doi.org/10.1016/0304-405X(94)90028-0

KocziszKy, G.-BENEDEK, J.-SZENDI, D. (2018): The impact of the 2008 financial crisis on household income and wealth in Visegrad countries Regional Statistics 8(1): 141-167. https://doi.org/10.15196/RS080102

KovÁCS, S. Zs. (2014): Elérhetôség és kirekesztés Magyarországon a pénzügyi szolgáltatások aspektusából Területfejlesztés és Innováció 8(3): 28-35.

LÖSCH, A. (1954): The Economics of Location Yale University Press, New Haven.

Malkiel, B. G. (1998): A Random Walk down Wall Street International Banking Training Center, Budapest.

Regional Statistics, Vol. 9. No. 1. 2019: 13-31; DOI: 10.15196/RS090110 
Markowitz, H. (1952): Portfolio Selection The Journal of Finance 7(1): 77-91. https://doi.org/10.1111/j.1540-6261.1952.tb01525.x

O'BriEn, R. (1992): Global Financial Integration: The End of Geography Council on Foreign Relations Press, New York.

ObstFeld, M.-TAYLOR, A. M. (2003): Globalization and Capital Markets Globalization in Historical Perspective University of Chicago Press, Chicago.

PÁlosi-NÉmeth, B. (2007): A feltörekvő országok tőkepiaca a pénzügyi globalizációban $\mathrm{PhD}$ dissertation, Debrecen.

SÁGVÁRI, B. (2019): Tér és társadalom Big Data szemüvegen keresztül Területi Statisztikea 59(1): 27-48. https://doi.org/10.15196/TS590102

SoLNIK, B. (1974): Why not diversify internationally rather than domestically Financial Analysts Journal 30(4): 48-54. https://doi.org/10.2469/faj.v51.n1.1864

SolNIK, B. (1982): Optimal international asset allocation Journal of Portfolio Management 9(1): 11-21. https://doi.org/10.3905/jpm.1982.408895

ZsıBÓK, Zs. (2017): Continuing divergence after the crisis: long-term regional economic development in the United Kingdom Regional Statistics 7(1): 17-42. https://doi.org/10.15196/RS07102

\section{INTERNET REFERENCES}

abszoluthozam.hu/images/kockazat.png databank.worldbank.org, sdw.ecb.europa.eu

Domestic vs. International equity portfolio risk. http://abszoluthozam.hu/images/kockazat.png (downloaded: January 2, 2016.)

sdw.ecb.europa.eu

Yahoo Finance (https:/ / finance.yahoo.com) 